\title{
Prosopis nigra fruits waste characterization, a potential source of functional ingredients for food formulations
}

\author{
María Jorgelina Pérez $^{\text {a,b, }}$, Ivana Fabiola Rodriguez ${ }^{\text {a,b, } 1}$, Iris Catiana Zampini ${ }^{\text {a,b,c, }}$, \\ Florencia Cattaneo $^{\mathrm{a}, \mathrm{b}}$, María Inés Mercado ${ }^{c}$, Graciela Ponessa ${ }^{\mathrm{c}}$, María Inés Isla ${ }^{\mathrm{a}, \mathrm{b}, \mathrm{c}, *}$ \\ ${ }^{a}$ Laboratorio de Investigación de Productos Naturales (LIPRON), Instituto de Bioprospección y Fisiología Vegetal (INBIOFIV-CONICET-UNT), Argentina \\ ${ }^{\mathrm{b}}$ Facultad de Ciencias Naturales e IML, Universidad Nacional de Tucumán, San Miguel de Tucumán, Argentina \\ c Instituto de Morfología Vegetal, Área Botánica, Fundación Miguel Lillo, Miguel Lillo 251, San Miguel de Tucumán, Tucumán, Argentina
}

\section{A R T I C L E I N F O}

\section{Keywords:}

Prosopis nigra

Fruits waste

Free phenolics

Bound phenolics

Functional ingredients

\begin{abstract}
A B S T R A C T
Prosopis nigra fruits are consumed in Argentina principally as fine flour. The plant material with the highest granulometry is considered a waste. Metabolites such as phenolics compounds, fibers, and proteins obtained from vegetable by-products or waste can be used as ingredients for new functional foods. The present study describes the characterization of $P$. nigra fruits waste to use as non-conventional sources of potential functional ingredients. The waste material with particle sizes $>149 \mu \mathrm{m}$ was processed to obtain powders with different granulometry named F1 $(>840 \mu \mathrm{m}), \mathrm{F} 2(840-500 \mu \mathrm{m})$, and F3 $(500-149 \mu \mathrm{m})$. All powders have a high fiber and fructose content. F3 have a homogeneous aspect with a high mesocarp proportion, mainly rich in free and bound phenolic compounds, C-glycosides derivates from apigenin, fibers, potassium and iron. Also, its phenolic enriched extract shows high antioxidant activity and inhibitory activity of enzymes related to carbohydrate metabolism ( $\alpha$-glucosidase and $\alpha$-amylase). F1 were less homogeneous and were enriched in sucrose and fructose, digestible starch and phenolic components, showed antioxidant capacity and high effectiveness as lipase inhibitor. Therefore, the powder obtained from $P$. nigra fruits waste has a great potential to be a novel renewable, sustainable, and low-cost raw material for the production of food formulations to reduce the risk of metabolic syndrome development.
\end{abstract}

\section{Introduction}

An attractive approach from the economic point of view is to recover the high-added-valued constituents present in fruits processing wastes. Fruit processing industries contribute more than 0.5 billion tons of waste worldwide. The global availability of this feedstock, together with its untapped potential, has encouraged researchers to perform detailed studies on value-addition potential of fruit processing waste. Both primary and secondary metabolites are valuable substances that have been extracted from fruits waste (Pfaltzgraff, Cooper, Budaria \& Clark, 2013). Cellulose can be recovered and converted into sugars and then into biofuels and biochemicals products (Joglekar, Pathak, Mandavgane \& Kulkarni, 2019). Additionally, some fruits waste showed high protein content that could be used (Fasoli \& Righetti, 2015). Many of secondary metabolites of fruit waste such as phenolic compounds have a wide range of action which includes antioxidant, anti-inflammatory, antibacterial, antifungal, anti-obesity, antitumor, cardioprotective, antihypertensive, etc. (Shahidi \& Yeo, 2018).

Prosopis nigra (Griseb.) Hieronymus, also known as 'Algarrobo negro', is an arboreal legume that grows in the arid and semi-arid environments of Argentina. It provides important ecological and social benefits as a barrier against winds and as a stabilizer for dunes; it is also a promising resource for reforestation and recovery of soils. $P$. nigra bark is appreciated as a potent astringent and dyeing agent. The wood is valuable for its use in construction, as well as for firewood and charcoal; whereas the leaves are used as fertilizer or composting and as fodder for ruminants (Pérez et al., 2014).

Prosopis nigra fruits are sweet aromatic pods consumed as flour, as a jam (arrope) or as a beverage (añapa or aloja) (Pérez, 2017; Pérez et al., 2014). The P. nigra flour was included in Argentine Food Code (Código

\footnotetext{
* Corresponding author. Laboratorio de Investigación de Productos Naturales (LIPRON), Instituto de Bioprospección y Fisiología Vegetal (INBIOFIV-CONICETUNT), Facultad de Ciencias Naturales e IML. UNT. Argentina.

E-mail address: misla@tucbbs.com.ar (M.I. Isla).

1 Both authors have the same participation.
} 
Alimentario Argentino, CAA, 2010). Fourteen flavonoid glycosides, C-glycosyl flavonoids and O-flavonol glycosides identified in $P$. nigra pod perform important antioxidant and anti-inflammatory activities in vitro (Cardozo et al., 2010; Pérez et al., 2014; Picariello et al., 2017). In addition, the anthocyanins responsible for fruit colour was determined (Pérez et al., 2014). Pericarp fine flours (particle size $\leq 149 \mu \mathrm{m}$ ) have proven to be attractive ingredients for their nutritional aspects, chemical composition and functional properties, namely antioxidant, antiinflammatory and effect on enzymes linked to metabolic syndrome metabolic (Pérez, Zampini, Alberto \& Isla, 2018). The P. nigra commercial flour was used as substrate for the enzymatic production of fructo-oligosaccharides (FOS) by Lactobacillus delbrueckii subsp. bulgaricus CIDCA 333, a strain particularly sensitive to any kind of stress (Romano, Sciammaro, Mobili, Puppo, \& Gomez-Zavaglia, 2018). Other authors analyzed the nutritional contribution of gluten-free bread made with Prosopis nigra flour, and the acceptability measured by celiac and non-celiac individuals (Torrelio Martos \& López, 2018). Previous reports experimentally verified that $P$. nigra pods flour are not genotoxic or mutagenic (Cardozo et al., 2010; Pérez et al., 2014, 2018). The only report of $P$. nigra toxicity is in cattle. Such a report is based on the observation of $P$. nigra in the region where sick animals are found and Prosopis sp. seeds are present in the rumen. All the clinical signs described are in agreement with the information obtained from cattle experimentally intoxicated with Prosopis juliflora pods containing piperidine alkaloids (Micheloud, Colque Caro, Cholich, Martinez, \& Gimeno, 2019). In effect, these alkaloids were assigned as responsible for causing damage to the mitochondria in the neurons of the central nuclei (Micheloud et al., 2019). However, these toxic components were not reported in $P$. nigra. The alkaloid tryptamine, occurring in low amounts, was identified in the $P$. nigra pods flour (Pérez et al., 2014). Tryptamine, the important psychotropic drug having indole ring, has a wider biological and pharmaceutical significance (neurotransmitter and neuromodulator, vasoconstrictor, vasodilator, antibacterial, antioxidant and antifungal agents (Kousara, Anjuma, Jaleela, Khana, \& Naseema, 2017). The $P$. nigra pods have ancestrally been used as livestock feed and for humans. In general, aborigines prefer $P$. nigra rather than $P$. alba to obtain flour because it is sweeter but has a stronger taste (Sciammaro, Ribotta, \& Puppo, 2016). The aim of the present work was to realize morphological, chemical and functional characterization of Prosopis nigra fruits waste to use as non-conventional sources of potential functional ingredients.

\section{Materials and methods}

\subsection{Sample preparation and processing}

P. nigra (Grisebach) Hieronymus ripe pods were collected in Amaicha del Valle, Tucumán, Argentina in March 2017. The pods were brushed and dried at $50{ }^{\circ} \mathrm{C}$ until reaching constant weight. Then, they were ground in Helix mill. Pericarp flour (epicarp + mesocarp) was passed through $149 \mu \mathrm{m}$ sieves to obtain commercial flour (fine flour) and waste material with granulometric grade $>149 \mu \mathrm{m}$. The waste material was passed through two sieves: 840 and 500 mesh. First recovered fraction F1 $(>840 \mu \mathrm{m})$, second fraction F2 $(840-500 \mu \mathrm{m})$, third fraction F3 $(500-$ $149 \mu \mathrm{m})$.

\subsection{Morphological and histological analysis}

$P$. nigra pod anatomy was studied in three pods from three different specimens. For anatomical characterization, the middle segment, comprising one seed, of each pod was mounted on dental wax supports and sectioned (thickness range $25-30 \mu \mathrm{m}$ ) with a rotary microtome (MicromHM315). The cuts were treated according to Rodriguez et al. (2019).

Epicarp, mesocarp and endocarp segments, seeds and powders (F1, F2, F3) were mechanically separated under a stereoscopic magnifying glass and subjected to maceration for $2-48 \mathrm{~h}$ in $10 \% \mathrm{KOH}$, washed with distilled water, mounted on glycerinated water (1:1) and observed under optical microscope. Pericarp sections and powder samples were subjected to histochemical tests with Sudan IV for lipids, $10 \% \mathrm{FeCl}_{3}$ for phenolic compounds, KI and polarized light for starch, $1 \%$ picric acid and $1 \%$ acid fuchsin for proteins and $5 \%$ Toluidine Blue O (TBO) for other carbohydrates and polysaccharides (Rodriguez et al., 2019).

All tissues and powder were analyzed with a Zeiss Stemi 2000-C stereoscopic microscope, and a Zeiss Axiolab optic microscope both equipped with a Zeiss Axiocam ERc 5s digital camera. Measurements were made by using the AxioVision software version 4.8.2 (Carl Zeiss Ltd, Herts, UK). For scanning electron microscopy (SEM), dry pod samples and fractions F1, F2 and F3 were coated with gold (Fine Coat Ion Sputter JEOL JFC-1100). Scanning electron microscopy (SEM) of gold coated samples was performed by using a ZEISS SUPRA-55 VP field emission scanning electron microscope.

\subsection{Chemical composition}

\subsubsection{Carbohydrates determination}

Powders obtained from $P$. nigra waste were extracted exhaustively with $80 \%$ aqueous ethanol $(1 \mathrm{~g}: 4 \mathrm{~mL})$ at $75^{\circ} \mathrm{C}$ and total sugars, reducing sugars, glucose, fructose and sucrose were determined according to Rodriguez et al., 2019.

Analysis of resistant and soluble starch was carried out according to Pérez et al., 2018 by enzymatic hydrolysis by pepsin and $\alpha$-amylase. Glucose content was determined by enzymatic glycaemia assay.

Fiber content was determined by acid and alkaline digestion according to Jaafar, Rahman, Mahmod \&Vasudevan (2009).

\subsubsection{Total protein analysis and amino acid composition}

Total protein content was determined by Kjeldahl method using a conversion factor of 6.25 (AOAC 920.87).

\subsubsection{Fat analysis}

Fat was determined by extracting powders with petroleum ether $\left(40-60{ }^{\circ} \mathrm{C}\right)$ in a Soxhlet apparatus for $4 \mathrm{~h}$ (AOAC 920.85).

\subsubsection{Determination of moisture, ash and minerals composition}

Moisture content was determined by drying for $12 \mathrm{~h}$ at $120{ }^{\circ} \mathrm{C}$ (AOAC, 1998 Official Method 925.09). The ash content was determined by incineration method (AACC 08-01, 2000). The mineral analysis was carried out by quadrupole inductively plasma mass spectrometry in accordance with AOAC (2000) recommendations.

\subsubsection{Phytochemicals analysis}

2.3.5.1. Free and bound polyphenolic compounds quantification. Powders obtained from $P$. nigra waste were extracted with ethanol:water (EtOH: $\left.\mathrm{H}_{2} \mathrm{O}\right), 70: 30(1: 10 \mathrm{w} / \mathrm{v})$ ultrasound assisted for $1 \mathrm{~h}$ at $25{ }^{\circ} \mathrm{C}$. The phenolic enriched extracts were filtered and the EtOH evaporated "in vacuo" (free-phenolics). The residual insoluble material was treated with $2 \mathrm{~N} \mathrm{NaOH}$ and then, with $4 \mathrm{M} \mathrm{HCl}$, filtered and extracted several times with ethyl acetate. The ethyl acetate fraction was dried under reduced pressure and then reconstituted with $1 \mathrm{~mL}$ of EtOH to obtain bound-phenolic enriched extract (bound-phenolics). The phenolic content was determined by Folin-Ciocalteu reagent, according to Singleton, Orthofer Lamuela-Raventos (1999). Total non-flavonoid phenolic compounds were determined by using the method described by Isla, Salas, Danert, Zampini, and Ordoñez (2014); they were determined by difference between total phenolic compounds and non-flavonoid phenolics.

2.3.5.2. Identification and quantification of phenolic compounds. Phenolic compound identification was carried out by HPLC-ESI-MS/MS. 

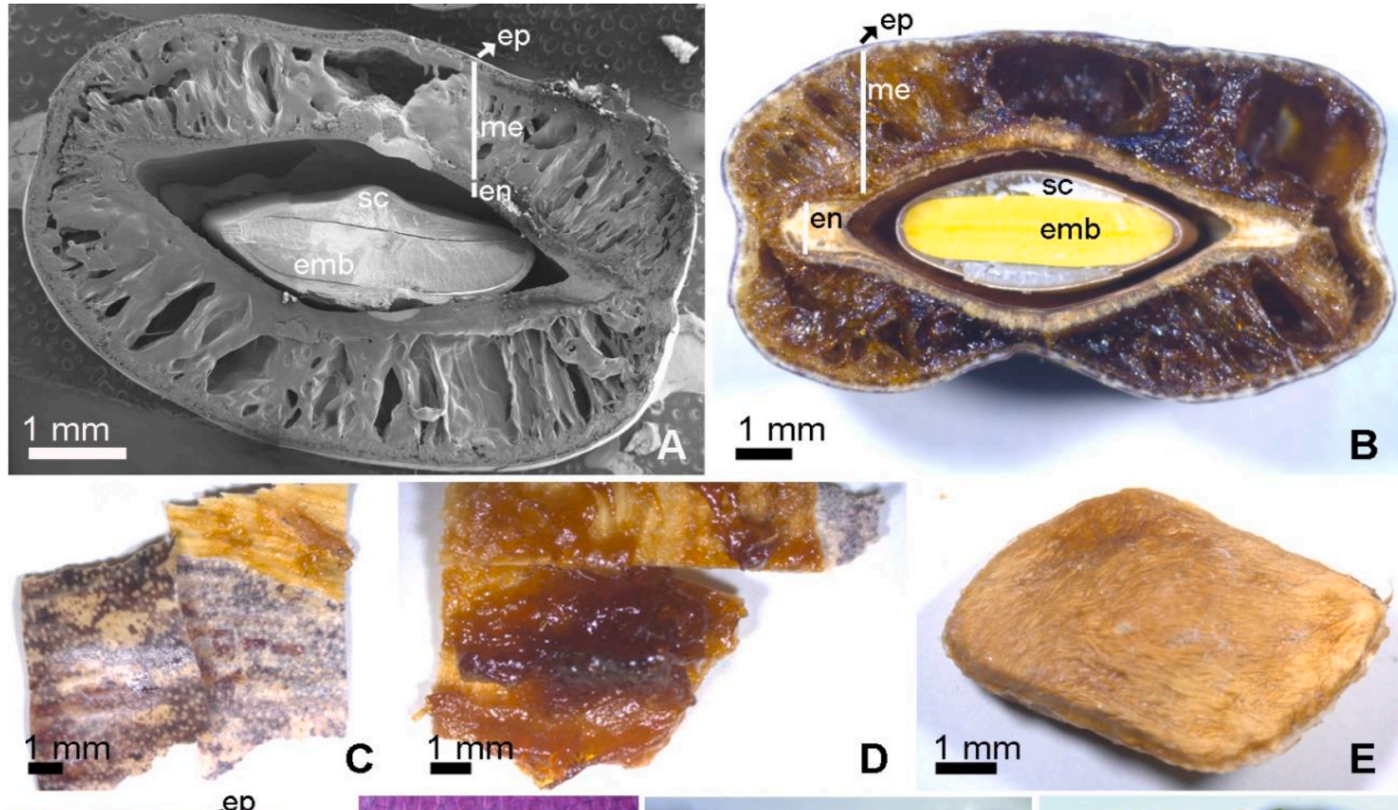

$1 \mathrm{~mm}$

B
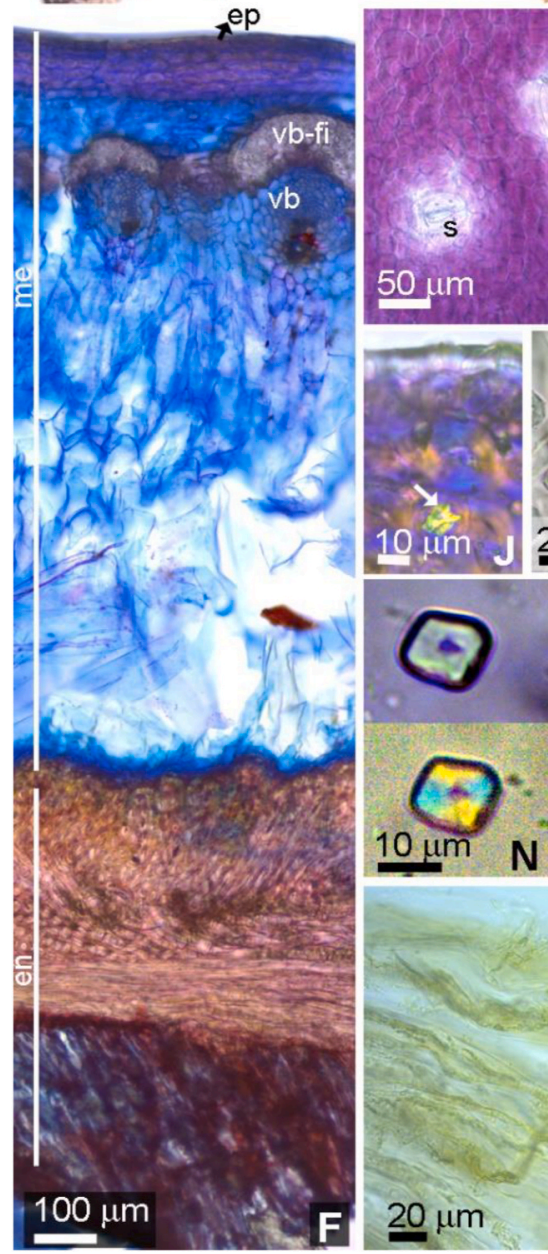

D $1 \mathrm{~mm}$

E
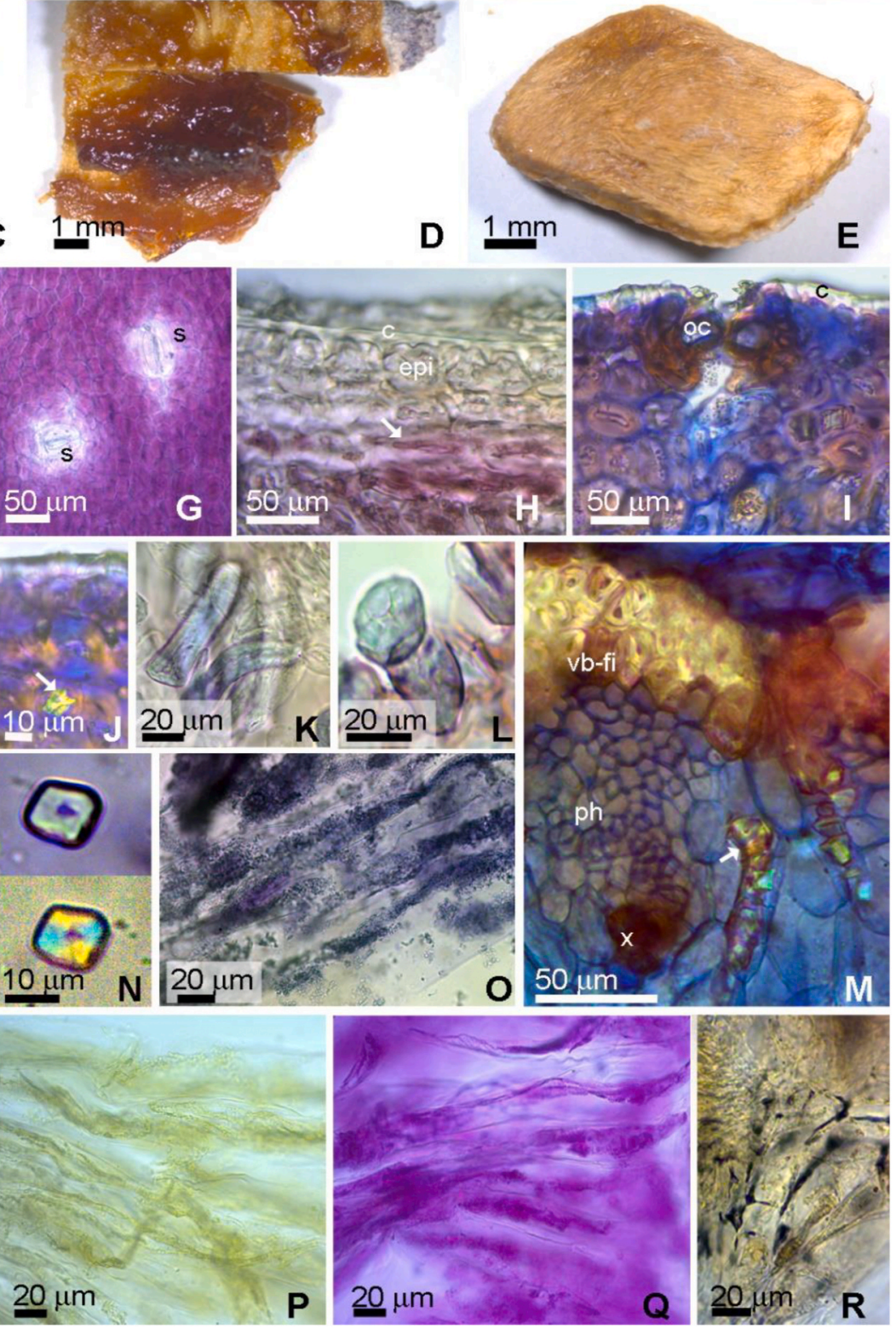

Fig. 1. Prosopis nigra fruit morphological and anatomical aspects. A. SEM of pericarp and seed. B. Pericarp and seed under stereoscopic microscopy. C-E. Isolated parts of the fruit under stereoscopic microscopy. C. Isolated epicarp aspect. D. Isolated mesocarp aspect. E. Isolated endocarp aspect. F. Fruit anatomy, cross section under light microscopy. G. Epicarp epidermal cells with anomocytic stomata. H. Epidermis cross section detail. I. Stomata. J. Calcium oxalate druse in subepidermal tissues (arrow). K. Macrosclereids. L. Brachysclereids. M. Vascular bundle, fibers and calcium oxalate prismatic crystals (arrow) observed in the mesocarp under polarized light. N. Starch granules under bright and polarized light. O. Polysacharides stained with TBO in mesocarp parenchymatic storage cells. P-Q. Proteins in mesocarp parenchymatic storage cells, stained with picric acid and acid fuschin respectively. $\mathbf{R} . \mathrm{FeCl}_{3}$ revealed the presence of phenolic compounds in paravascular reserved parenchyma.

Abbreviations: c, cuticle; emb, embryo; en, endocarp; ep, epicarp; epi, epidermis; me, mesocarp; oc, occlusive cell; ph, phloem; s, stomata; sc, seed coat; vb, vascular bundle; vb-fi, vascular bundle fibers; $x$, xylem. 
The HPLC system was connected to a QTOF mass spectrometer (rmicroTOF-QII Series, Bruker), with an electro spray ionization (ESI) source. Mass spectra were recorded in negative ion mode between $\mathrm{m} / \mathrm{z}$ 50 and 1000 . Ionization was performed at $4500 \mathrm{~V}$ assisted by nitrogen as a nebulizer gas at $4.0 \mathrm{bar}$, and as a drying gas at $200^{\circ} \mathrm{C}$ and a flow rate of 8.0 L. $\mathrm{min}^{-1}$. Argon was used as a collision gas. MS detector was programmed to perform MS and alternative MS/MS from the three most abundant ions obtained with a collision energy of $12 \mathrm{eV}$. Data acquisition and processing were performed by using a Compass Version 3.1 software and a Data Analysis Version 4.0 software, respectively (Bruker Daltonics, MA-USA).

Free and bound polyphenolic compounds of extract obtained from Prosopis powder of different granulometries were analyzed by HPLC coupled to a diode array detector (HPLC-DAD) (Waters Corporation, Milford, MA, USA) in an analytical C18 column (XBridge). This was done by using a linear gradient solvent system consisting of $0.1 \%$ acetic acid in water (A) and $0.1 \%$ acetic acid in methanol, as follows: $35 \%-20 \% \mathrm{~A}$ over $10 \mathrm{~min}, 20 \%-0 \%$ A from 10 to $20 \mathrm{~min}, 0 \%$ A for $10 \mathrm{~min}$. Compounds were monitored at $254 \mathrm{~nm}$, and $220-540 \mathrm{~nm}$ UV spectra were recorded for peak characterization. Polyphenol quantification was based on external calibration curves from available phenolic standards (HPLC grade-Sigma-Aldrich (MO, USA), Fluka Chemical Corp. (USA) and Indofine Chemical Company, Inc.). Results were given as $\mu \mathrm{g}$ equivalents of standard compounds employed per mg of phenolic dry weight.

2.3.5.3. Anthocyanin analysis. The anthocyanin extraction was performed by using acidified methanol (1\%) ultrasound, assisted and quantified by using pH differential method (Pérez et al., 2014). Data were expressed as $g$ of cyanidin-3-glucoside equivalents (g C3G-E)/100 g powder.

\subsection{Antioxidant capacity}

In all cases, the bound and free phenolic enriched extracts and the identified phenolic compounds in the extracts, namely ferulic and coumaric acids, vicenin II and schaftoside, were assayed.

\subsubsection{Free radicals scavenging capacity}

The free radical scavenging activity was measured by using phenolic compounds concentrations up to 50 or $400 \mu \mathrm{g} \mathrm{GAE} / \mathrm{mL}$. The ABTS ${ }^{\bullet+}$ scavenging activity was followed by the $\mathrm{ABTS}^{\bullet+}$ method as described by Re et al. (1999). The hydrogen peroxide scavenging activity was analyzed by using the methodology described by Chamira Preethi (2015). The hydroxyl radical scavenging activity was determined according to Cattaneo et al. (2016). Superoxide radicals scavenging activity was determined by using both a non-enzymatic (Valentao et al., 2002) and an enzymatic method (Cos et al., 1998). The capacity of nitric oxide scavenger was determined according to Kumaran Karunakaran (2006).

\subsubsection{Lipid peroxidation inhibition capacity}

Antioxidant activity was determined according to Rodriguez et al. (2019) by using $\beta$-carotene linoleic acid system. IC 50 values denote the $\mu \mathrm{g} \mathrm{GAE} / \mathrm{mL}$ required to inhibit $\beta$-carotene bleaching by $50 \%$.

\subsection{Inhibitory activity of enzymes related to metabolic syndrome}

The effect on metabolic syndrome enzymes ( $\alpha$-Glucosidase, $\alpha$-Amylase and Lipase) was evaluated following Pérez et al., 2018. The bound and free phenolic enriched extracts and the phenolic compounds identified in the extracts, namely ferulic and coumaric acids, vicenin II and schaftoside, were assayed. $\mathrm{IC}_{50}$ values denote the phenolics concentration ( $\mu \mathrm{g} \mathrm{GAE} / \mathrm{mL}$ ) required to inhibit the enzymatic activity by $50 \%$. Acarbose $(1-50 \mu \mathrm{g} / \mathrm{mL})$ and Orlistat $(0.1-20 \mu \mathrm{g} / \mathrm{mL})$ were used as
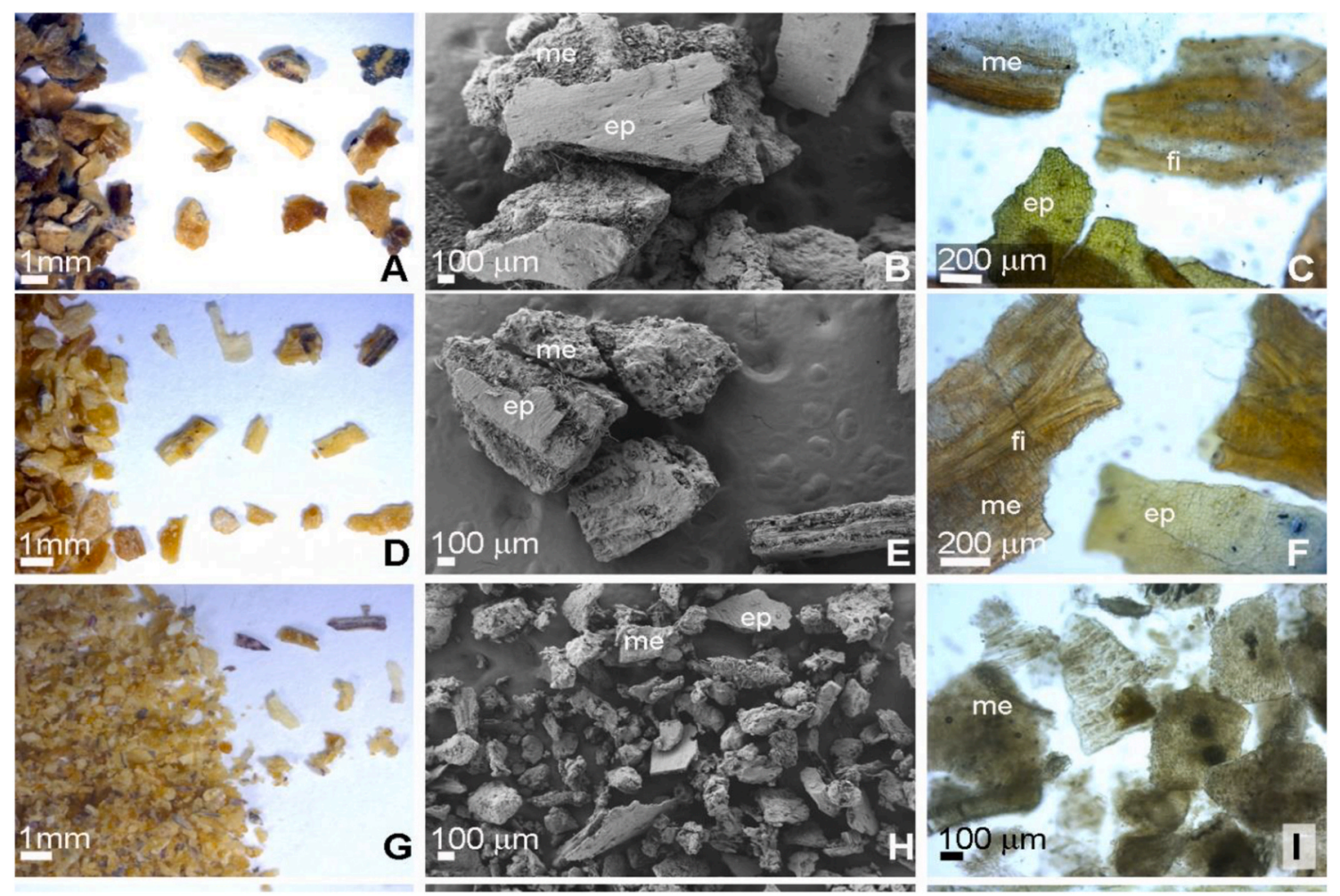

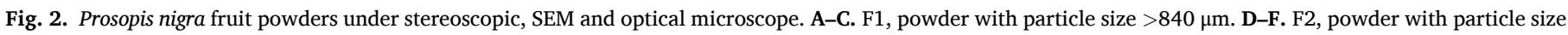
between 840 and $500 \mu \mathrm{m}$. G-I. F3, powder with particle size between 500 and $149 \mu \mathrm{m}$.

Abbreviations: ep, epicarp; me, mesocarp; fi, fibers; ms, macrosclereids. 
reference compounds.

\subsection{Statistical analyses}

Analyses were performed in triplicate with three different samples. Each experimental value is expressed as the mean \pm standard deviation (SD). The statistic software InfoStat (Student Version, 2011) was used to evaluate the significance of differences between groups. The one-way ANOVA with Tukey post-test at a confidence level of $95 \%$ was used for the comparisons between groups.

\section{Results and discussion}

The wastes from the "algarrobo negro" fine flour production could potentially be a good feedstock for recovery of bioactive compounds. Powders with different particle size (F1, F2, F3) obtained from waste material of $P$. nigra fruits were characterized morphologically and chemically. The polyphenolic compounds enriched extracts obtained from each fraction were characterized to use as functional ingredients.

\subsection{Characterization of powder with different particle sizes obtained} from $P$. nigra pod wastes

\subsubsection{Macroscopic and microscopic characters}

The 'algarrobo negro' pod is an indehiscent, apiculated, submonilifom, straight to slightly curved drupaceous legume classified as lomentum drupaceum, made up by the pericarp or the fruit itself and the seeds (Fig. 1A and B). Three layers constitute the pericarp, namely epicarp, mesocarp and endocarp (Fig. 1A-F). The epicarp presents a papiraceous light brown aspect with purple spots due to the presence of anthocyanins (Pérez et al., 2014), shiny on the upper side to opaque on the underside (Fig. 1C and $\mathrm{H}$ ); its epidermal cells are polyhedral with straight to slightly curved anticlinal walls and anomocytic stomata (52.1 $\pm 14.5 \mu \mathrm{m}$ long., $26.6 \pm 7.2 \mu \mathrm{m}$ lat.) (Fig. 1G). In cross section, it presents a thick cuticle, 1 layer of epidermal cells (Fig. 1F) with thick walls and stomata sunken with respect to the epidermal surface, with the occlusive cells showing a cuticular ridge (Fig. 1I). The anthocyanins, observed as spots in paradermal view, are accumulated in the subepidermal strata of the mesocarp (Fig. 1H), a pulpy and edible brown mass with a sweet characteristic aroma (Fig. 1D). The cross section shows 2-4 layers of peripheral collenchyma, sclereids (brachy and macrosclereids) sometimes not lignified, with anthocyanins and calcium oxalate druses or prismatic crystals, abundant reserve parenchyma and vascular bundles (Fig. 1F and H-L). The latter are collateral with strong fiber reinforcements towards the phloem (Fig. $1 \mathrm{~F}$ and $\mathrm{M}$ ) and calcium oxalate prismatic crystals in the nearby parenchyma (Fig. $1 \mathrm{~F}$ and $\mathrm{M}$ ). It was difficult to distinguishing native starch granules in this tissue due to its opacity, but free starch granules presenting faceted surfaces with centric hilum and maltese cross with linear arms were observed (Fig. 1N). Similar granules were previously described for $P$. flexuosa, $P$. chilensis and P. alba (Giovannetti, Lema, Bartoli \& Capparelli, 2008; Rodriguez et al., 2019). The presence of other sugars was detected with TBO in parenchymatic storage cells from mesocarp (Fig. 1O). Fuchsin acid and picric acid also revealed the presence of proteins in these cells (Fig. 1P-Q) as stated for this species by Cardozo et al. (2010). Phenolic compounds were detected with $\mathrm{FeCl}_{3}$ in the reserve parenchyma, exclusively near the vascular bundles (Fig. 1R). No lipids were detected.

The endocarp is hard and segmented into one-seeded joints (Fig. 1E), formed exclusively by lignified fibers arranged perpendicular to the longitudinal axis of the fruit (Fig. 1F).

Prosopis nigra powders, fractions F1, F2 and F3, are formed exclusively by fragments of epicarp and mesocarp in different proportions (Fig. 2A-I). Fractions F1 and F2 showed approximately 75 to $60 \%$ of epicarp and $25-40 \%$ of mesocarp respectively (Fig. 2A-F), whereas fractions F3 showed greater proportions of mesocarp, representing 50\% in F3 (Fig 2G-I).
Table 1

Macronutrient content of powders from Prosopis nigra pod waste with different particle sizes.

\begin{tabular}{|c|c|c|c|}
\hline \multirow[t]{2}{*}{ Samples } & $\mathrm{F} 1$ & $\mathrm{~F} 2$ & F3 \\
\hline & \multicolumn{3}{|l|}{ (g/100 g Powder) } \\
\hline Total carbohydrates & $68.48 \pm 1.00^{\mathrm{A}}$ & $65.65 \pm 1.00^{\mathrm{A}}$ & $67.21 \pm 1.50^{\mathrm{A}}$ \\
\hline Glucose & $1.91 \pm 0.05^{\mathrm{A}}$ & $2.09 \pm 0.02^{\mathrm{A}}$ & $2.34 \pm 0.02^{\mathrm{A}}$ \\
\hline Fructose & $36.92 \pm 0.44^{\mathrm{A}}$ & $27.72 \pm 0.12^{\mathrm{B}}$ & $26.54 \pm 0.03^{\mathrm{B}}$ \\
\hline Sucrose & $46.10 \pm 2.10^{\mathrm{A}}$ & $32.66 \pm 1.10^{\mathrm{B}}$ & $33.24 \pm 1.20^{\mathrm{B}}$ \\
\hline Resistant starch & $2.21 \pm 0.02^{\mathrm{A}}$ & $1.72 \pm 0.0^{\mathrm{B}}$ & $1.48 \pm 0.02^{\mathrm{B}}$ \\
\hline Digestible starch & $14.89 \pm 0.10^{\mathrm{A}}$ & $4.27 \pm 0.03^{\mathrm{B}}$ & $1.01 \pm 0.01^{\mathrm{C}}$ \\
\hline Total starch & $17.1^{\mathrm{A}}$ & $5.99^{\mathrm{B}}$ & $2.49^{\mathrm{C}}$ \\
\hline Ash & $4.32 \pm 0.02^{\mathrm{B}}$ & $5.90 \pm 0.03^{\mathrm{A}}$ & $4.33 \pm 0.02^{\mathrm{B}}$ \\
\hline Moisture (\%) & $33.97 \pm 0.02^{\mathrm{A}}$ & $30.29 \pm 0.02^{\mathrm{B}}$ & $34.76 \pm 0.03^{\mathrm{A}}$ \\
\hline Proteins & $11.81 \pm 0.19^{\mathrm{A}}$ & $11.49 \pm 0.34^{\mathrm{A}}$ & $12.84 \pm 0.39^{\mathrm{A}}$ \\
\hline Fats & $0.96 \pm 0.01^{\mathrm{B}}$ & $0.87 \pm 0.01^{\mathrm{B}}$ & $1.44 \pm 0.02^{\mathrm{A}}$ \\
\hline Fibers & $14.41 \pm 0.72^{\mathrm{B}}$ & $16.09 \pm 0.53^{\mathrm{A}}$ & $14.18 \pm 0.43^{\mathrm{B}}$ \\
\hline Minerals & \multicolumn{3}{|l|}{ ( $\mu \mathrm{g} / \mathrm{g}$ flour) } \\
\hline $\mathrm{Mg}$ & $480 \pm 6^{\mathrm{B}}$ & $540 \pm 6^{\mathrm{A}}$ & $555 \pm 8^{\mathrm{A}}$ \\
\hline $\mathrm{K}$ & $10062 \pm 170^{\mathrm{A}}$ & $10837 \pm 220^{\mathrm{A}}$ & $10702 \pm 170^{\mathrm{A}}$ \\
\hline $\mathrm{Na}$ & $11 \pm 0.00^{\mathrm{A}}$ & $11 \pm 0.00^{\mathrm{A}}$ & $11 \pm 0.00^{\mathrm{A}}$ \\
\hline $\mathrm{Ca}$ & $1910 \pm 60^{\mathrm{A}}$ & $1970 \pm 20^{\mathrm{A}}$ & $1750 \pm 140^{\mathrm{A}}$ \\
\hline $\mathrm{Cu}$ & $0.00 \pm 0.00$ & $0.00 \pm 0.00$ & $0.00 \pm 0.00$ \\
\hline $\mathrm{Fe}$ & $30 \pm 0.00^{\mathrm{B}}$ & $40 \pm 0.00^{\mathrm{B}}$ & $60 \pm 0.00^{\mathrm{A}}$ \\
\hline $\mathrm{Zn}$ & $0.00 \pm 0.00$ & $0.00 \pm 0.00$ & $0.00 \pm 0.00$ \\
\hline
\end{tabular}

F1: Powder with particle size $>840 \mu \mathrm{m}, \mathrm{F} 2$ : Powder with particle size between 840 and $500 \mu \mathrm{m}, \mathrm{F3}$ : Powder with particle size between 500 and $149 \mu \mathrm{m}$. Different letters (A, B, C) in the same line for each assay show significant differences according to Tukey's test ( $\mathrm{p} \leq 0.05)$.

\subsubsection{Chemical characterization}

Moisture, protein, fat, ash, sugar and starch content for powders from Prosopis pod waste were determined as shown in Table 1. Total carbohydrate content was similar in all powders (around 65\%) and lower compared with $P$. nigra fine flour (77\%) and wheat flour $(72 \%)$. Berrios et al. (2010) reported similar carbohydrate content in lentils and chickpeas (62.49-65.7\%). Sucrose and fructose were the major sugars present in $P$. nigra powders of different particle sizes. The highest sucrose and fructose content were observed in powders with the largest particle size (46.10 and $36.92 \%$, respectively) and the lowest sucrose and fructose contents were previously reported in fine flour with the smallest particle size (Pérez et al., 2018). Taking into account its high content of sucrose and fructose, $P$. nigra waste powder could be used as nutritional ingredient or substrate to enzymatic production of FOS (Romano et al., 2018).

Total starch percentage of Prosopis waste powder was higher in those with the highest particle size $(17.1 \%)$ than the lowest particle size powder $(2.42 \%)$. The starch content was lower than in sorghum, millet and corn (72.2-73.8\%), quinoa, amaranth and wheat (66.3-68.1\%), (Srichuwong, 2017). Soluble digestible starch content was highest in the powder with the largest particle size. Resistant starch content was below $2.2 \%$ in every powder fractions (Table 1 ). These results suggest that starch is not the main energy source of $P$. nigra waste material and are in agreement with those found by micrographic analyses.

The fiber content in powder was not affected by particle size in F1, F2 and F3. Total fiber content in all fractions was $14.18-16.09 \%$ similar to other legumes such as Glycine max (14\%, Silagadze, Pruidze, Gachechiladze, Pkhakadze, \& Khvadagiani, 2017), Vicia fava and Pisum sativum (Millar, Gallagher, Burke, McCarthy, \& Barry-Ryan, 2019), but higher than fine flour from P. nigra (6.34 $\pm 0.19 \%$, Pérez et al., 2018), as well as of other legumes such as Arachis hypogaea (8.4\%, Bonku \& Yu, 2020) or cereals such as wheat (10.08\%, Millar et al., 2019). However, the content was lower than in Lens culinaris $26.86 \%$ (Dueñas et al., 2016). According to European Parliament Regulation (EC) Number $1924 / 2006$, these powders could be considered as a food with high fiber content and could be used for enriching foods since an inverse association between dietary fibre and the risk of metabolic syndrome was 
Table 2

Phenolics components of powders from $P$. nigra pod waste with different granulometry.

\begin{tabular}{|c|c|c|c|c|c|c|c|}
\hline Samples & $\begin{array}{l}\text { Free phenolic } \\
\text { compounds (mgGAE/ } \\
100 \mathrm{~g} \text { powder) }\end{array}$ & $\begin{array}{l}\text { Non-flavonoid } \\
\text { phenolics (mgGAE/ } \\
100 \text { g powder) }\end{array}$ & $\begin{array}{l}\text { Flavonoid } \\
\text { phenolics } \\
\text { (mgGAE/100 g } \\
\text { powder) }\end{array}$ & $\begin{array}{l}\text { Bound phenolic } \\
\text { compounds mgGAE/ } \\
100 \mathrm{~g} \text { powder) }\end{array}$ & $\begin{array}{l}\text { Bound flavonoid } \\
\text { phenolics (mgGAE/ } \\
100 \text { g powder) }\end{array}$ & $\begin{array}{l}\text { Bound non- flavonoid } \\
\text { phenolics (mgGAE/ } \\
100 \mathrm{~g} \text { powder) }\end{array}$ & $\begin{array}{l}\text { Anthocyanins (mg } \\
\text { C3GE/g powder) }\end{array}$ \\
\hline $\mathrm{F} 1$ & $147.45 \pm 1.32^{\mathrm{B}}$ & $0.25 \pm 0.02^{\mathrm{B}}$ & $147.20 \pm 0.60^{\mathrm{B}}$ & $36.96 \pm 1.70^{\mathrm{B}}$ & $0.32 \pm 0.02^{\mathrm{B}}$ & $36.64 \pm 0.04^{C}$ & $574.28 \pm 5.05^{\mathrm{A}}$ \\
\hline $\mathrm{F} 2$ & $143.17 \pm 8.52^{\mathrm{B}}$ & $0.17 \pm 0.00^{\mathrm{C}}$ & $143.00 \pm 4.10^{\mathrm{B}}$ & $45.04 \pm 3.20^{\mathrm{A}}$ & $0.21 \pm 0.00^{\mathrm{C}}$ & $44.83 \pm 0.04^{\mathrm{B}}$ & $441.85 \pm 1.27^{\mathrm{C}}$ \\
\hline F3 & $181.87 \pm 12.12^{\mathrm{A}}$ & $0.33 \pm 0.05^{\mathrm{A}}$ & $181.54 \pm 6.30^{\mathrm{A}}$ & $48.08 \pm 2.10^{\mathrm{A}}$ & $0.41 \pm 0.06^{\mathrm{A}}$ & $47.67 \pm 0.03^{\mathrm{A}}$ & $558.60 \pm 4.39^{B}$ \\
\hline
\end{tabular}

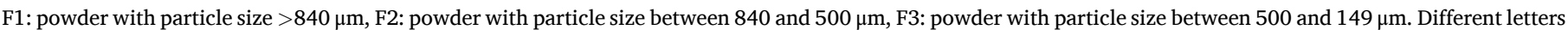
$(\mathrm{A}, \mathrm{B}, \mathrm{C})$ in the same column for each assay show significant differences among chemical components content according to Tukey's test ( $\mathrm{p} \leq 0.05$ ).

observed in several epidemiologic studies (Hosseinpour-Niazi, Mirmiran, Sohrab, Hosseini-Esfahani, \& Azizi, 2011).

Regarding protein content, there were not significant differences between F1, F2 and F3 (Table 1) and was higher than fine flour $(7.5 \%$, Pérez et al., 2018) and similar to a $P$. nigra commercial flour which does not contain toxic prolamins (13\%, Torrelio Martos \& López, 2018) and cereal flour such as wheat or maize but lower than other legume flour such as soy, lentil and chickpea (Days, 2013).

Due to their protein content, these powders could be used to complement other flours, thus lending a characteristic flavor and color, similar to chocolate or coffee, as described by Margalef et al. (2012).

The fat content was less than $1.5 \%$ in all fractions. F3 showed the highest fat level (Table 1) but lower than that reported for fine flour (3.44\%, Pérez et al., 2018) or the $P$. nigra commercial flour $(4.8 \%$, Torrelio Martos \& López, 2018). This offers an advantage over other legume flour such as chickpea and soy flours that have a higher fat content (Day, 2013). The presence of high levels of fat can be a barrier to incorporating the flours into foods because their oxidation could affect both the flavour and shelf-life of some food products.

Regarding minerals, $\mathrm{Zn}$ and $\mathrm{Cu}$ were not detected in any fraction. Potassium was the most abundant element, followed by $\mathrm{Ca}, \mathrm{Mg}$, and Fe. The content of $\mathrm{K}, \mathrm{Ca}$ and $\mathrm{Mg}$ was not influenced by particle size. These results would indicate a distribution in all tissues of Prosopis pods waste. Cereals as well as legumes, are considered important sources of minerals in the diet (Albergamo et al., 2018; Oghbaei \& Prakash, 2016). However, wheat flour is low in $\mathrm{Mg}, \mathrm{K}$ and $\mathrm{Ca}(0.22,0.9$ and $0.58 \mathrm{mg} / \mathrm{g}$ of flour, respectively, Wang et al., 2020), compared with Prosopis pod waste flour. Furthermore, the Na content is high in wheat flours (40.2 $\mathrm{mg} / \mathrm{g}$ flour, Wang et al., 2020) while in Prosopis pod waste flour, it is low and consequently these products can be regarded as a food without sodium since its values are lower than $5 \mathrm{mg} / 100 \mathrm{~g}$ powder and could be included in special diets (Table 1 ). All three fractions had a significantly higher content of iron compared to wheat flour and green pea and similar content to fava bean (Millar et al., 2019). F3 showed the highest iron content; this fraction has greater proportions of mesocarp (50\%), a fact which would indicate that the mesocarp is a tissue enriched by this mineral. According with dietary reference values of minerals (mg/day) for adults, the Prosopis pod waste flours could be considered high in $\mathrm{K}$ ( $600 \mathrm{mg} /$ day) and iron ( $4.4 \mathrm{mg} /$ day) and a source of Ca (120 mg/day) (European Food Safety Authority, 2016). The use of waste flours in food products in the diet could make a substantial contribution to meeting daily mineral requirements.

Free phenolic compounds were four-fold more abundant than bound phenolics in F1, F2 and F3 (Table 2). Fraction F3 exhibited a higher content of bound phenolic compounds than F1 and F2. The unequal distribution of the bound phenolic compounds in the Prosopis powder could probably be related to the particle size; the extraction efficiency increases with the decrease in particle size due to the larger contact surface that allows a greater interaction with the solvent. Following the same behavior as bound phenolic compounds, F3 was richer in free phenolic compounds. The total phenolic content was similar to other legume flour such as green pea, chickpea, lentil, soybean flour (1.34; $1.54 ; 2.44 ; 2.35 \mathrm{mg} \mathrm{GAE} / \mathrm{g}$, Xu \& Chang, 2007) and higher than cereal flour. Bound phenolics are considered to have more health benefits since
Table 3

Assignment of the Prosopis nigra pod waste polyphenols based on HPLC ESI-MS/ MS spectra. Q: quercetin; K: kaempferol; glc: Glucoside.

\begin{tabular}{|c|c|c|c|c|c|}
\hline $\begin{array}{l}\text { Peak } \\
\text { no. }\end{array}$ & $\begin{array}{l}\mathrm{Rt} \\
(\mathrm{min})\end{array}$ & $\begin{array}{l}{[\mathrm{M}-} \\
\mathrm{H}]^{-}\end{array}$ & $\begin{array}{l}{[\mathrm{M}-\mathrm{H}]^{-}} \\
\text {Fragments - } \\
\text { negative ion } \\
\text { mode }\end{array}$ & assignment & References \\
\hline 1 & 23.0 & 163 & 119 & Coumaric acid & $\begin{array}{l}\text { Pérez et al. } \\
\text { (2018) }\end{array}$ \\
\hline 2 & 23.7 & 593 & $\begin{array}{l}503,473,431, \\
383,353\end{array}$ & $\begin{array}{l}\text { Apigenin 6C glc 8C } \\
\text { glc }\end{array}$ & $\begin{array}{l}\text { Picariello et al. } \\
\text { (2017) }\end{array}$ \\
\hline 3 & 23.9 & 593 & $\begin{array}{l}575,503,473, \\
383,353\end{array}$ & Vicenin II & $\begin{array}{l}\text { Pérez et al. } \\
\text { (2014) }\end{array}$ \\
\hline 4 & 25.1 & 193 & 134 & Ferulic acid & $\begin{array}{l}\text { Pérez et al. } \\
\text { (2018) }\end{array}$ \\
\hline 5 & 26.6 & 563 & $\begin{array}{l}545,503,473, \\
443,383,353\end{array}$ & Isoschaftoside & $\begin{array}{l}\text { Pérez et al., } \\
2014 \text {; } \\
\text { Picariello } \\
\text { et al., } 2017\end{array}$ \\
\hline 6 & 26.7 & 625 & 300 & Q-dihexoside & $\begin{array}{l}\text { Pérez et al. } \\
\text { (2014) }\end{array}$ \\
\hline 7 & 27.3 & 563 & $\begin{array}{l}545,503,473, \\
443,383,353\end{array}$ & Schaftoside & $\begin{array}{l}\text { Pérez et al., } \\
2014 \text {; } \\
\text { Picariello } \\
\text { et al., 2017 }\end{array}$ \\
\hline 8 & 31.3 & 431 & $353,341,311$ & Isovitexin & $\begin{array}{l}\text { Pérez et al., } \\
2014 ; \\
\text { Picariello } \\
\text { et al., } 2017\end{array}$ \\
\hline 9 & 32.5 & 609 & 301 & $\begin{array}{l}\text { Q-hexoside- } \\
\text { rhamnose }\end{array}$ & $\begin{array}{l}\text { Pérez et al. } \\
\text { (2014) }\end{array}$ \\
\hline 10 & 35.4 & 643 & $461,299,269$ & $\begin{array}{l}\text { not identified } \\
\text { (rhamnoside- } \\
\text { hexoside } \\
\text { derivative) }\end{array}$ & \\
\hline 11 & 35.6 & 609 & 301 & $\begin{array}{l}\text { Q-hexoside- } \\
\text { rhamnose }\end{array}$ & $\begin{array}{l}\text { Pérez et al. } \\
\text { (2014) }\end{array}$ \\
\hline 12 & 36.1 & 463 & 301 & Q-hexoside & $\begin{array}{l}\text { Pérez et al. } \\
\text { (2014) }\end{array}$ \\
\hline 13 & 36.8 & 623 & 315 & $\begin{array}{l}\text { Q- methyl ether- } \\
\text { hexoside- } \\
\text { rhamnoside }\end{array}$ & $\begin{array}{l}\text { Pérez et al. } \\
\text { (2014) }\end{array}$ \\
\hline 14 & 37 & 447 & 285 & K-hexoside & $\begin{array}{l}\text { Pérez et al. } \\
\text { (2014) }\end{array}$ \\
\hline 15 & 48 & 301 & 171 & not identified & \\
\hline 16 & 48.3 & 387 & 297 & $\begin{array}{l}\text { not identified (C- } \\
\text { glycoside } \\
\text { derivative) }\end{array}$ & \\
\hline
\end{tabular}

they may escape from upper gastrointestinal digestion conditions along with cell wall materials and absorbed into blood plasma during digestion by intestinal microflora (Acosta-Estrada, Gutierrez-Uribe \& Serra-Saldivar, 2014). Therefore, consumption of F3 fraction might increase absorbed free and bound phenolics. The same behavior was observed in free and bound flavonoid and non-flavonoid phenolic compound. Powders with different granulometries may be suitable as a functional ingredient but powder with lower particle size (F3) could be healthier because of their high content of bound phenolic compounds and could be used either alone or together. Fine flour also has 2.65 times more free phenolics than bound phenolics (Pérez et al., 2018). 

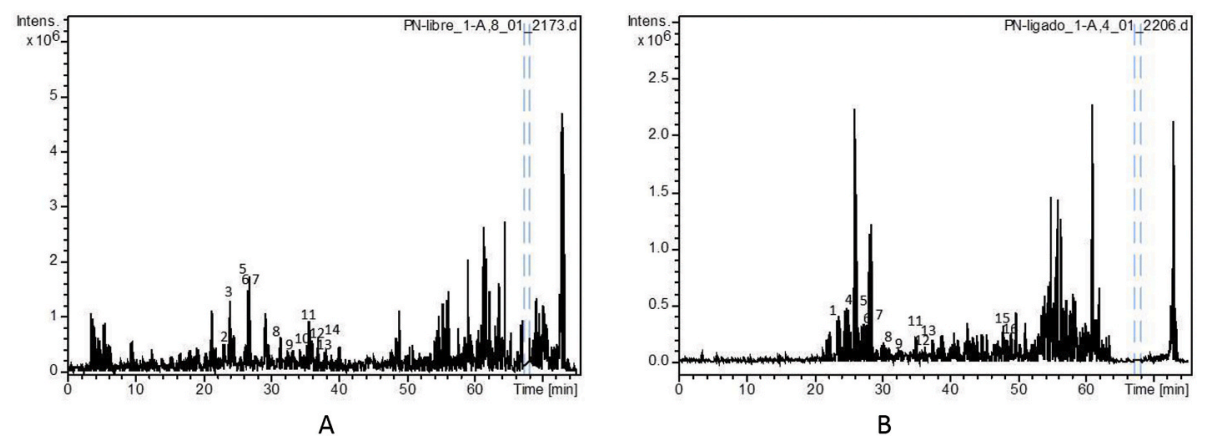

Fig. 3. HPLC-MS Chromatograms of A) P. nigra waste Free phenolics and B) P. nigra waste Bound phenolics.

Table 4

Phenolics content of $P$. nigra extracts enriched in free and bound phenolic compounds of powders with different granulometry obtained from pod waste.

\begin{tabular}{|c|c|c|c|c|}
\hline \multirow[t]{2}{*}{ Samples } & \multicolumn{2}{|c|}{ Free phenolic compounds } & \multicolumn{2}{|c|}{ Bound phenolic compounds } \\
\hline & Vicenin II & Schaftoside & Coumaric acid & Ferulic acid \\
\hline \multicolumn{5}{|c|}{$\mu \mathrm{g} / \mathrm{mg} \mathrm{DW}$} \\
\hline $\mathrm{F} 1$ & $0.16 \pm 0.02^{\mathrm{B}}$ & $0.23 \pm 0.01^{B}$ & $4.58 \pm 0.02^{\mathrm{B}}$ & $2.17 \pm 0.01^{\mathrm{C}}$ \\
\hline F2 & $0.18 \pm 0.01^{\mathrm{B}}$ & $0.25 \pm 0.02^{\mathrm{B}}$ & $4.90 \pm 0.01^{\mathrm{B}}$ & $2.99 \pm 0.02^{\mathrm{B}}$ \\
\hline F3 & $0.22 \pm 0.01^{\mathrm{A}}$ & $0.33 \pm 0.01^{\mathrm{A}}$ & $6.55 \pm 0.01^{\mathrm{A}}$ & $3.44 \pm 0.02^{\mathrm{A}}$ \\
\hline
\end{tabular}

F1: powder with particle size $>840 \mu \mathrm{m}, \mathrm{F} 2$ : powder with particle size between 840 and $500 \mu \mathrm{m}$, F3: powder with particle size between 500 and $149 \mu \mathrm{m}$. Different letters (A, B, C) in the same column for each assay show significant differences among chemical components content according to Tukey's test ( $\mathrm{p} \leq$ 0.05).

Apigenin-based C-glycosides were identified (Tables 2 and 3 and Fig. 3) and quantified in free phenolic-enriched extracts from Prosopis pod waste powder (Table 4). C-glycoside content was higher in powders with smaller granulometries. Vicenin II $(0.22 \pm 0.03 \mu \mathrm{g} / \mathrm{mg}$ dry extract) and schaftoside $(0.33 \pm 0.03 \mu \mathrm{g} / \mathrm{mg}$ dry extract $)$ were the major components in material with lowest granulometry (F3) (Table 4). Both compounds were also reported in Prosopis alba seed and mesocarp flour and Ceratonia siliqua seed samples (Schmeda-Hirschmann et al., 2015; Cattaneo et al., 2016; Picariello et al., 2017; Rodríguez et al., 2019). C-glycosil compounds were also identified in wheat granules (Liu, Qiu, \& Beta, 2010). These compounds exhibit antioxidant, anti-inflammatory, antiplatelet activity, anti-cancer, anti-hypertensive, hypoglycemic activities, among others (Xiao, Capanoglu, Jassbi \& Miron, 2016; Cattaneo et al., 2019). Besides, they are rapidly absorbed after oral administration and distributed by plasma in various tissues (Xiao et al., 2016). Other compounds identified in free phenolic-enriched extracts from Prosopis pod waste were kaempferol and quercetin O-glycosides (Fig. 3, Table 3). These compounds were previously reported by Pérez et al. (2014). Many studies have described the beneficial effects of kaempferol and quercetin derivatives in reducing the risk of chronic diseases, especially as antioxidant, anti-inflammatory, anti-obesity, neuroprotective (Dok-Go et al., 2003; Chen \& Chen, 2013; Li et al., 2020).

Ferulic acid and coumaric acid were identified and quantified in bound phenolic-enriched extracts obtained from Prosopis waste powders. The highest content was obtained from F3 fraction (ferulic acid: $6.55 \pm 0.36 \mu \mathrm{g} / \mathrm{mg}$ dry extract and coumaric acid: $3.44 \pm 0.35 \mu \mathrm{g} / \mathrm{mg}$ dry extract) (Table 4). Ferulic acid was also reported as the most dominant phenolic acid in wheat, constituting up to $79 \%$ of the total phenolic acids (Liu et al., 2010; Wang et al., 2020). Antioxidant activity of ferulic acid has been associated with several positive health effects, mainly anti-carcinogenic, neuro-protective, vascular-protective, antioxidant, antiinflammatory (Bento-Silva, Vaz Patto \& Bronze, 2018; Seo et al., 2015). Pérez et al., 2018 reported the presence of vicenin II, schaftoside, isovitexin, isoschaftoside, protocatechuic acid, coumaric and ferulic acids in $P$. nigra pod fine flour $(<149 \mu \mathrm{m})$. In these studies, protocatechuic acid was not found in powders with particle size between 840 and $149 \mu \mathrm{m}$.

Pérez et al., 2014 and 2018, also reported the presence of anthocyanins in fine flour of $P$. nigra pods as the pigment responsible for fruit colour. In powders of different granulometry (F1, F2 and F3) obtained from $P$. nigra pod wastes, a similar content of pigments was found in all of them (441.85-574.28 mg C3GE/g powder). Hydrosoluble pigment levels were higher than in other anthocyanin-rich foods such as blueberries (1.3-3.8 mg/g FW) and purple corn (6.8-82.3 mg/g FW) (He et al., 2016; Lao \& Giusti 2017). The legume seeds, i.e., lentils, peas, soybeans and common beans, primarily contain phenolic acids derived from benzoic acid and phenylpropanoids, as well as flavonoids (mainly catechins and procyanidins and O-glycosil flavonoids), (Singh, Singh, Kaur, \& Singh, 2017; Zhang et al., 2015). Prosopis waste, instead, mainly

Table 5

Antioxidant activity of free and bound phenolic enriched extracts obtained from powders with different granulometry of pod waste.

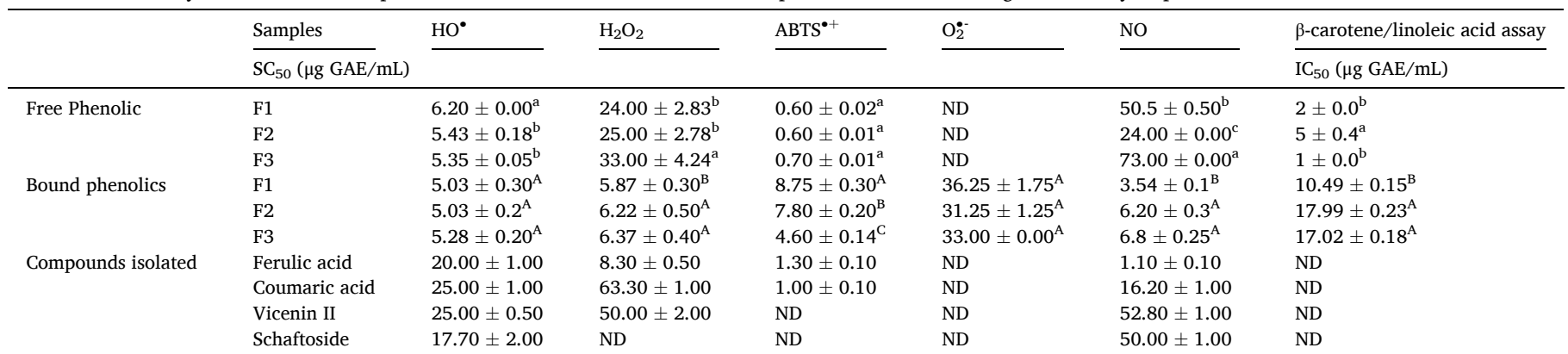

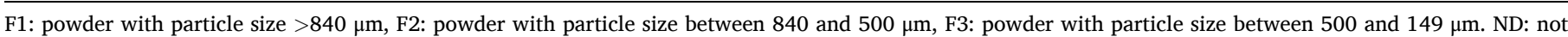

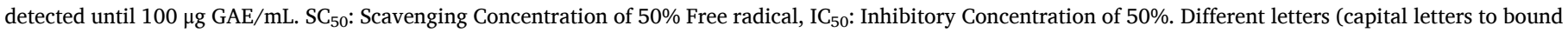
phenolic; lower case letter to free phenolic) in the same column for each antioxidant assay show significant differences according to Tukey's test ( $\mathrm{p} \leq 0.05$ ). 
has phenylpropanoid derivatives and flavonoids with C-glycosidic linkage.

\subsubsection{Functional characterization}

3.1.3.1. Antioxidant capacity. Antioxidant molecules could help to attenuate redox unbalance and oxidative damage reduce. Table 5 shows antioxidant activity of free and bound phenolic enriched extracts and identifies compounds from powders from Prosopis nigra pod wastes. It was found that, with increasing concentrations of phenolics, $\mathrm{H}_{2} \mathrm{O}_{2}$ linearly decreased, thus indicating that these compounds could effectively scavenge $\mathrm{H}_{2} \mathrm{O}_{2}$. $\mathrm{SC}_{50}$ values of bound phenolics enriched extracts were between 5.87 and $6.37 \mu \mathrm{g} / \mathrm{mL}$ (Table 5). The $\mathrm{H}_{2} \mathrm{O}_{2}$ scavenging activity of bound phenolic compounds enriched extracts was higher than that of free phenolic compounds enriched extracts $\left(\mathrm{SC}_{50}=24-33 \mu \mathrm{g} / \mathrm{mL}\right.$ ). The F1 was more active than F3 in both phenolic types. The antioxidant effect could be probably due to the ferulic and coumaric acid in the bound phenolic extract and $\mathrm{C}$-glycosil flavones in the free phenolic extract. Ferulic acid showed a $\mathrm{SC}_{50}$ of $8.3 \mu \mathrm{g} / \mathrm{mL}$ against $\mathrm{H}_{2} \mathrm{O}_{2}$, lower values than those obtained for coumaric acid, also present in the bound phenolic enriched extract. The apigenin derivate C-glycoside compounds present in free phenolic enriched extracts, such as vicenin II, showed weak activity against $\mathrm{H}_{2} \mathrm{O}_{2}$, while schaftoside was inactive. This result would indicate that the activity of the free phenolic enriched extract would be due to the synergistic effect between several constituents present in the extract.

Both bound and free phenolic compounds enriched extracts showed hydroxyl radical scavenging activity (Table 5) with $\mathrm{SC}_{50}$ values of $5.03-6.20 \mu \mathrm{g} / \mathrm{mL}$. The identified compounds showed $\mathrm{SC}_{50}$ values around $20 \mu \mathrm{g} / \mathrm{mL}$ lower than the $\mathrm{SC}_{50}$ values of the extracts. Only the bound phenolic enriched extracts from F1, F2 and F3 were active on superoxide anion radical with $\mathrm{SC}_{50}$ values around $30 \mu \mathrm{g} / \mathrm{mL}$, while ferulic and coumaric acid were inactive on this ROS. In regards to NO scavenging, the bound phenolic enriched extracts were more active $\left(\mathrm{SC}_{50}\right.$ values between 3.5 and $6.8 \mu \mathrm{g} / \mathrm{mL}$ ) than the free phenolic enriched extracts ( $\mathrm{SC}_{50}$ values between $2473 \mu \mathrm{g} / \mathrm{mL}$ ).

F1, F2 and F3 showed $\mathrm{ABTS}^{\bullet+}$ scavenging capacity with $\mathrm{SC}_{50}$ values between 0.6 and 0.7 for free phenolic enriched extracts and 4.6-8.75 $\mu \mathrm{g}$ $\mathrm{GAE} / \mathrm{mL}$ for bound phenolic enriched extracts. Ferulic and cumaric acid of bound phenolic fraction showed activity against $\mathrm{ABTS}^{\bullet+}$ with $\mathrm{SC}_{50}$ of 1.30 and $1.00 \mu \mathrm{g} \mathrm{GAE} / \mathrm{mL}$, respectively. Vicenin II and schaftoside were not active on ABTS cation radical up to $100 \mu \mathrm{g}$ GAE/mL. This result would indicate that the activity of the free phenolic enriched extracts would be due to the synergistic effect between several constituents present in the extract.

Powders with different particle size showed inhibitory activity on lipid peroxidation. The free phenolic enriched extracts ( $\mathrm{IC}_{50}$ values between 1 and $5 \mu \mathrm{g} \mathrm{GAE} / \mathrm{mL}$ ) were more active than the bound phenolic enriched extract ( $\mathrm{IC}_{50}$ values between 10.49 and $17.99 \mu \mathrm{g} \mathrm{GAE} / \mathrm{mL}$ ). Pérez et al. (2018) reported lower antioxidant activity for extracts enriched in free and bound phenolic compounds obtained from $P$. nigra fine flour than fractions with higher granulometry obtained from $P$. nigra waste. The bioactive phenolic compounds present in $P$. nigra waste as reactive metabolites associated antioxidant activity make them suitable candidates for creating new functional foods. The antioxidant capacity and health-promoting activities of several legumes, as well as its relation with phenolic profile, was described although its activity was attributed to phenolic compounds different from those presented in the study matrix (Singh et al., 2017).

\subsubsection{Effect of phenolic enriched extracts on key enzyme linked to metabolic syndrome}

3.1.3.2.1. $\alpha$-Glucosidase and $\alpha$-amylase inhibition. The inhibition of enzymes linked to carbohydrate metabolism is relevant to the management of type-II diabetes. The free phenolic enriched extracts from
Table 6

Effect of phenolic enriched extracts on key enzyme involved in the development of metabolic syndrome.

\begin{tabular}{|c|c|c|c|c|}
\hline & \multirow[t]{2}{*}{ Samples } & \multirow{2}{*}{$\begin{array}{l}\alpha \text {-Amylase } \\
\mathrm{IC}_{25} / \mathrm{IC}_{50}(\mu \mathrm{g} \\
\mathrm{GAE} / \mathrm{mL})\end{array}$} & \multirow{2}{*}{$\begin{array}{l}\alpha \text {-Glucosidase } \\
\mathrm{IC}_{50}(\mu \mathrm{g} \mathrm{GAE} / \\
\mathrm{mL})\end{array}$} & \multirow{2}{*}{$\begin{array}{l}\text { Lipase } \\
\mathrm{IC}_{50}(\mu \mathrm{g} \\
\mathrm{GAE} / \mathrm{mL})\end{array}$} \\
\hline & & & & \\
\hline \multirow[t]{3}{*}{ Free phenolic } & $\mathrm{F} 1$ & $\begin{array}{l}\mathrm{IC}_{25=} 40.00 \pm \\
1.00^{\mathrm{a}}\end{array}$ & $4.16 \pm 0.16^{b}$ & $\begin{array}{l}2.50 \pm \\
0.02^{\mathrm{b}}\end{array}$ \\
\hline & $\mathrm{F} 2$ & $\begin{array}{l}\mathrm{IC}_{25=} 30.00 \pm \\
2.00^{\mathrm{b}}\end{array}$ & $1.60 \pm 0.00^{\mathrm{c}}$ & $\begin{array}{l}42.45 \pm \\
1.55^{\mathrm{a}}\end{array}$ \\
\hline & F3 & $\begin{array}{l}\mathrm{IC}_{25=} 10.00 \pm \\
1.00^{\mathrm{c}}\end{array}$ & $5.65 \pm 0.56^{\mathrm{a}}$ & $\begin{array}{l}41.25 \pm \\
0.25^{\mathrm{a}}\end{array}$ \\
\hline \multirow[t]{3}{*}{$\begin{array}{l}\text { Bound } \\
\text { phenolics }\end{array}$} & $\mathrm{F} 1$ & $\begin{array}{l}\mathrm{IC}_{50}=18.65 \pm \\
1.00^{\mathrm{A}}\end{array}$ & $3.25 \pm 0,15^{\mathrm{B}}$ & $\begin{array}{l}5.95 \pm \\
0.25^{\mathrm{B}}\end{array}$ \\
\hline & F2 & $\begin{array}{l}\mathrm{IC}_{25}=9.74 \pm \\
0.50^{\mathrm{B}}\end{array}$ & $2.03 \pm 0,18^{\mathrm{C}}$ & $\begin{array}{l}3.80 \pm \\
0.40^{\mathrm{B}}\end{array}$ \\
\hline & F3 & $\begin{array}{l}\mathrm{IC}_{25}=11.77 \pm \\
1.00^{\mathrm{B}}\end{array}$ & $7.48 \pm 0.58^{\mathrm{A}}$ & $\begin{array}{l}29.40 \pm \\
0.80^{\mathrm{A}}\end{array}$ \\
\hline \multirow[t]{4}{*}{$\begin{array}{l}\text { Compounds } \\
\text { isolated }\end{array}$} & Ferulic acid & $\begin{array}{l}\mathrm{IC}_{50}=66.00 \pm \\
0.71\end{array}$ & $3.50 \pm 0.02$ & $\begin{array}{l}13.00 \pm \\
1.41\end{array}$ \\
\hline & $\begin{array}{l}\text { Coumaric } \\
\text { acid }\end{array}$ & $\begin{array}{l}\mathrm{IC}_{50}=61.00 \pm \\
0.58\end{array}$ & $3.15 \pm 0.50$ & $\begin{array}{l}25.00 \pm \\
3.99\end{array}$ \\
\hline & Vicenin II & $\mathrm{ND}$ & $10.00 \pm 0.50$ & $\begin{array}{l}8.50 \pm \\
0.50\end{array}$ \\
\hline & Schaftoside & ND & $3.80 \pm 0.20$ & $\begin{array}{l}13.50 \pm \\
1.00\end{array}$ \\
\hline
\end{tabular}

F1: powder with particle size $>840 \mu \mathrm{m}$, F2: powder with particle size between 840 and $500 \mu \mathrm{m}$, F3: powder with particle size between 500 and $149 \mu \mathrm{m}$. ND: not detected until $100 \mu \mathrm{g} \mathrm{GAE} / \mathrm{mL}$. IC $\mathrm{I}_{25}$ : Inhibitory Concentration of $25 \%$ of enzyme activity. IC ${ }_{50}$ : Inhibitory Concentration of $50 \%$ of enzyme activity. Different letters (capital letters to bound phenolic; lower case letter to free phenolic) in the same column for each assay of enzyme inhibition show significant differences according to Tukey's test $(\mathrm{p} \leq 0.05)$.

Prosopis waste were active on $\alpha$-glucosidase ( $\mathrm{IC}_{50}$ between 1.6 and 5.65 $\mu \mathrm{g} \mathrm{GAE} / \mathrm{mL}$ ) and $\alpha$-amylase (IC 50 between 10 and $40 \mu \mathrm{g} \mathrm{GAE} / \mathrm{mL}$ ) although the power over the first enzyme was greater. The same behavior was shown by bound phenolic enriched extract with $\mathrm{IC}_{50}$ between 2.03 and $7.48 \mu \mathrm{g} \mathrm{GAE} / \mathrm{mL}$ (Table 5). The bound phenolic enriched extracts were better inhibitors for $\alpha$-amylase than free phenolic enriched extracts specially bound phenolic extracts obtained from F1 (Table 6). Both the free and bound phenolic obtained from F3 were more active than F1 and F2. Results suggest that extracts might be able to reduce glucose uptake/absorption. In this sense, powder with different granulometry obtained from $P$. nigra pod waste may be a dietary complement to control hyperglycemia in diabetic patients. Polyphenols, especially free polyphenols, obtained from $P$. nigra fine flour were also able to inhibit enzymes associated with the metabolic syndrome, including $\alpha$-amylase ( $\mathrm{IC}_{50} 30.1 \mu \mathrm{g} \mathrm{GAE} / \mathrm{mL}$ ) and $\alpha$-glucosidase ( IC $_{50} 22.5 \mu \mathrm{g} \mathrm{GAE} /$ $\mathrm{mL}$ ), Pérez et al., 2018. High inhibition ability of $\alpha$-glucosidase was produced by the phenolic extracts from other legumes such as lentil, bean and soybean cultivars (Moreno-Valdespino, Luna-Vital, Camacho-Ruiz \& Mojica, 2020; Tan \& Chang, 2017; Tan, Chan \& Zhang, 2017; Zhang et al., 2015).

3.1.3.2.2. Pancreatic lipase. Pancreatic lipase is an enzyme that plays an important role in metabolic syndrome in the lipid hydrolysis to form fatty acids in such a way that they can be absorbed in the human digestive tract. Bound phenolics present a higher lipase activity (3.80-29.40 $\mu \mathrm{g} \mathrm{GAE} / \mathrm{mL})$ than free phenolics $(2.5-42.45 \mu \mathrm{g} \mathrm{GAE} / \mathrm{mL})$, (Table 6). The same effect was reported for $P$. nigra fine flour (Pérez et al., 2018). Both the F1(free phenolic) and F1 and F2 (bound phenolic) fractions of $P$. nigra waste were more active on lipase than F3. Inhibition ability of lipase with $\mathrm{IC}_{50}$ values similar to commercial inhibitor by phenolic extracts has been reported for other legumes, that is, bean and soybean (Tan, Chan \& Zhang. 2017; Tan \& Chang, 2017; Zhang et al., 2015; Moreno-Valdespino, Luna-Vital, Camacho-Ruiz \& Mojica, 2020). 


\section{Conclusion}

The potential of food waste to create new opportunities and markets has been underestimated until recent years, when interest in converting this waste into valuable compounds has grown. The non-conventional powder of different granulometries obtained from $P$. nigra pod wastes can be considered as a functional food or as a functional ingredient in food formulations, a fact which could potentially reduce the risk of the development of obesity. In addition, this study provides useful information for food industries that are interested in improving the quality of processed food products with functional ingredients. Processing $P$. nigra pods waste may well become an important segment of agribusiness, if it is used as an eco-friendly strategy to minimize pollution; it also provides a way to produce high-value products from low-cost and abundant native fruit materials in Argentina.

\section{Declaration of competing interest}

The authors have declared that there is no conflict of interest.

\section{CRediT authorship contribution statement}

María Jorgelina Pérez: Writing - original draft, Formal analysis. Ivana Fabiola Rodriguez: Writing - original draft, Formal analysis. Iris Catiana Zampini: Writing - original draft, Formal analysis. Florencia Cattaneo: Formal analysis. María Inés Mercado: Writing - original draft, Formal analysis. Graciela Ponessa: Formal analysis. María Inés Isla: Writing - original draft, Formal analysis, Project administration.

\section{Acknowledgements}

The authors would like to acknowledge the financial support from the SCAIT-UNT (PIUNT G-533 and PIUNT G637), the Agencia Nacional de Promoción Científica y Técnica (ANPCyT, PICT 2014 No 3136 and PICT 2017 No 4436), the Consejo Nacional de Investigaciones Científicas y Técnicas (CONICET, PUE 2018-0011), Argentina.

\section{References}

AACC. (2000). Basic method 08-01 ash, crude protein-improved method Kjedahl method 46-10. In International approved methods of American Association of cereal chemists. St Paul, MN.

Acosta-Estrada, B., Gutiérrez-Uribe, J., \& Serna-Saldívar, S. (2014). Bound phenolics in foods, a review. Food Chemistry, 152, 46-55.

Albergamo, A., Bua, G. D., Rotondo, A., Bartolomeo, G., Annuario, G., Costa, R., et al. (2018). Transfer of major and trace elements along the "farm-to-fork" chain of different whole grain products. Journal of Food Composition and Analysis, 66, 212-220.

AOAC. (1998). In W. Horwitz (Ed.), Official method of analysis of AOAC international. Method 925.10 Solids (Total) and moisture in flour (Gaithersburg, Maryland, USA).

AOAC. (2000). In W. Horwitz (Ed.), Official methods of analysis of AOAC international (17th ed.) (Gaithersburg, Maryland, USA).

Bento-Silva, A., Vaz Patto, M. C., \& Bronze, M. R. (2018). Relevance, structure and analysis of ferulic acid in maize cell walls. Food Chemistry, 246, 360-378.

Berrios, J. J, Morales, P., Camara, M., \& Sanchez-Mata, M. C. (2010). Carbohydrate composition of raw and extruded pulse flours. Food Research International, 43, 531-536.

Bonku, R., \& Yu, J. (2020). Health aspects of peanuts as an outcome of its chemical composition. Food Science and Human Wellness, 9, 21-30.

Cardozo, M. L. Ordóñez, R. M., Zampini, I. C. Cuello, A. S., Di Benedetto, G., \& Isla, M. I. (2010). Evaluation of antioxidant capacity, genotoxicity and polyphenol content of non-conventional foods: Prosopis flour. Food Research International, 43, 1505-1510.

Cattaneo, F., Costamagna, M. S., Zampini, I. C., Sayago, J., Alberto, M. R., Chamorro, V., et al. (2016). Flour from Prosopis alba cotyledons: A natural source of nutrient and bioactive phytochemicals. Food Chemistry, 208, 89-96.

Cattaneo, F., Roco, J., Alarcon, G., Isla, M. I., \& Jerez, S. (2019). Prosopis alba seed flour improves vascular function in a rabbit model of high fat diet-induced metabolic syndrome. Heliyon, 5, Article e01967.

Chamira, D. F., \& Preethi, S. (2015). Optimized enzymatic colorimetric assay for determination of hydrogen peroxide $\left(\mathrm{H}_{2} \mathrm{O}_{2}\right)$ scavenging activity of plant extracts. Methods X, 2, 283-291.

Chen, A., \& Chen, Y. (2013). A review of the dietary flavonoid, kaempferol on human health and cancer chemoprevention. Food Chemistry, 138, 2099-2107.
Código Alimentario Argentino. (2010). Capítulo XIX: Harinas, concentrados, aislados y derivados proteínicos. Article 1407 and 1408.

Cos, P., Ying, L., Calomme, M., Hu, J. P., Cimanga, K., Van Poel, B., et al. (1998) Structure-activity relationship and classification of flavonoids as inhibitors of xanthine oxidase and superoxide scavengers. Journal of Natural Products, 61(1), $71-76$.

Day, L. (2013). Proteins from land plants - potential resources for human nutrition and food security. Trends in Food Science \& Technology, 32(1), 25-42.

Dok-Go, H., Lee, K., Kim, H., Lee, H., Lee, J., Song, Y., et al. (2003). Neuroprotective effects of antioxidative flavonoids, quercetin, (1)-dihydroquercetin and quercetin 3methyl ether, isolated from Opuntia ficus-indica var. saboten. Brain Research, 965, $130-136$.

Dueñas, M., Sarmento, T., Aguilera, Y., Benitez, V., Mollá, E., Esteban, R. M., et al. (2016). Impact of cooking and germination on phenolic composition and dietary fibre fractions in dark beans (Phaseolus vulgaris L.) and lentils (Lens culinaris L.). Food Science and Technology, 66, 72-78.

European Commission. (2016). EU register on nutrition and health claims. Available From European Commission EU Register on Health and Nutrition Claims. Retrieved 17/ 01/2017, from European Commission http://ec.europa.eu/food/safety/labelli ng_nutrition/claims/register/public/?event=search.

Fasoli, E., \& Righetti, P. G. (2015). Proteomics of fruits and beverages. Current Opinion in Food Science, 4, 76-85.

Giovannetti, M. A., Lema, V. S., Bartoli, C. G., \& Capparelli, A. (2008). Starch grain characterization of Prosopis chilensis (Mol.) Stuntz and P. flexuosa DC, and the analysis of their archaeological remains in Andean South America. Journal of Archaeological Science, 35, 2973-2985.

He, B., Zhang, L. L., Yue, X. Y., Liang, J., Jiang, J., Gao, X. L., et al. (2016). Optimization of ultrasound-assisted extraction of phenolic compounds and anthocyanins from blueberry (Vaccinium ashei) wine pomace. Food Chemistry, 204, 70-76.

Hosseinpour-Niazi, S., Mirmiran, P., Sohrab, G., Hosseini-Esfahani, F., \& Azizi, F. (2011). Inverse association between fruit, legume, and cereal fiber and the risk of metabolic syndrome: Tehran Lipid and Glucose Study. Diabetes Research and Clinical Practice, 94, 276-283.

Isla, M. I., Salas, A., Danert, F. C., Zampini, I. C., \& Ordoñez, R. M. (2014). Analytical methodology optimization to estimate the content of non-flavonoid phenolic compounds in Argentine propolis extracts. Pharmaceutical Biology, 52(7), 835-840.

Jaafar, A. R., Rahman, B. R. A., Mahmod, C. Z. N., \& Vasudevan, R. (2009). Proximate analysis of dragon fruit (Hylecereus polyhizus). American Journal of Applied Sciences, 6, 1341-1346.

Joglekar, S. N., Pathak, P. D., Mandavgane, S. A., \& Kulkarni, B. D. (2019). Process of fruit peel waste biorefinery: A case study of citrus waste biorefinery, its environmental impacts and recommendations. Environmental Science and Pollution Research, 26, 34713-34722.

Kousara, S., Anjuma, S., Jaleela, F., Khana, J., \& Naseema, S. (2017). Biomedical significance of tryptamine: A review. Journal Pharmacovigilance, 5, 5.

Kumaran, A., \& Karunakaran, R. J. (2006). Nitric oxide radical scavenging active components from Phyllanthus emblica L. Plant Foods for Human Nutrition, 61(1), 1-5.

Lao, F., \& Giusti, M. M. (2017). The effect of pigment matrix, temperature and amount of carrier on the yield and final color properties of spray dried purple corn (Zea mays L.) Cob anthocyanin powders. Food Chemistry, 227, 376-382.

Li, S., Pan, J., Hu, X., Zhang, Y., Gong, D., \& Zhang, G. (2020). Kaempferol inhibits the activity of pancreatic lipase and its synergistic effect with orlistat. Journal of Functional Foods, 72, 104041.

Liu, Q., Qiu, Y., \& Beta, T. (2010). Comparison of antioxidant activities of different colored wheat grains and analysis of phenolic compounds. Journal of Agricultural and Food Chemistry, 58, 9235-9241.

Margalef, M. I., Tóffoli, S. L., Burgos, V. E., Campos, A., Valdez Clinis, G. A., \& Jiménez, M. J. (2012). Algarroba Negra (Prosopis nigra): Caracterización fisicoquímica y elaboración de productos dietéticos. Revista de la Facultad de Ciencias de la Salud, 1(2), 14-19. Retrieved from: http://fsalud.unsa.edu.ar/salud/descar gas/revista/REVISTA2.pdf.

Micheloud, J. F., Colque Caro, L. A., Cholich, L. A., Martinez, O. G., \& Gimeno, E. J. (2019). Suspected poisoning in beef cattle from ingestion of Prosopis nigra pods in north-western Argentina. Toxicon, 157, 80-83.

Millar, K. A., Gallagher, E., Burke, R., McCarthy, S., \& Barry-Ryan, C. (2019). Proximate composition and anti-nutritional factors of fava-bean (Vicia faba), green-pea and yellow-pea (Pisum sativum) flour. Journal of Food Composition and Analysis, 82, 103233

Moreno-Valdespino, C. A., Luna-Vital, D., Camacho-Ruiz, R. M., \& Mojica, L. (2020). Bioactive proteins and phytochemicals from legumes: Mechanisms of action preventing obesity and type-2 diabetes. Food Research International, 108905.

Oghbaei, M., \& Prakash, J. (2016). Effect of primary processing of cereals and legumes on its nutritional quality: A comprehensive review. Cogent Food \& Agriculture, 2(1), 1136015.

Pérez, M. J. (2017). Revalorización de frutos nativos argentinos. Caracterización química y funcional de frutos de algarrobos. Argentina: $\mathrm{PhD}$. thesis. Universidad Nacional de Tucumán.

Pérez, M. J., Cuello, A. S., Zampini, I. C., Ordóñez, R. M., Alberto, M. R., Quispe, C., et al. (2014). Polyphenolic compounds and anthocyanin content of Prosopis nigra and Prosopis alba pods flour and their antioxidant and anti-inflammatory capacity. Food Research International, 64, 762-771.

Pérez, M. J., Zampini, I. C., Alberto, M. R., \& Isla, M. I. (2018). Prosopis nigra mesocarp fine flour, a source of phytochemicals with potential effect on enzymes linked to metabolic syndrome, oxidative stress, and inflammatory process. Journal of Food Science, 83(5), 1454-1462. 
Pfaltzgraff, L. A., Cooper, E. C., Budarin, V., \& Clark, J. H. (2013). Food waste biomass: A resource for high-value chemicals. Green Chemistry, 15, 307-314.

Picariello, G., Sciammaro, L., Siano, F., Volpe, M. G., Puppo, M. C., \& Mamone, G. (2017). Comparative analysis of C -glycosidic flavonoids from Prosopis spp. and Ceratonia siliqua seed germ flour. Food Research International, 99, 730-738.

Regulation (EC) No. (1924/2006). European parliament regulation.

Re, R., Pellegrini, N., Proteggente, A., Pannala, A., Yang, M., \& Rice-Evans, C. (1999). Antioxidant activity applying an improved ABTS radical cation decolorization assay. Free Radical Biology and Medicine, 26, 1231-1237.

Rodriguez, I. F., Pérez, M. J., Cattaneo, F., Zampini, I. C., Cuello, A. S., Mercado, M. I., et al. (2019). Morphological, histological, chemical and functional characterization of Prosopis alba flours of different particle sizes. Food Chemistry, 274, 583-591.

Romano, N., Sciammaro, L., Mobili, P., Puppo, M. C., \& Gomez-Zavaglia, A. (2018). Flour from mature Prosopis nigra pods as suitable substrate for the synthesis of prebiotic fructo-oligosaccharides and stabilization of dehydrated Lactobacillus delbrueckii subsp. bulgaricus. Food Research International, 121, 561-567.

Schmeda-Hirschmann, G., Quispe, C., Soriano, M., Theoduloz, C., Jiménez-Aspée, F., Pérez, M., et al. (2015). Chilean Prosopis mesocarp flour: Phenolic profiling and antioxidant activity. Molecules, 20(4), 7017-7033.

Sciammaro, L. P., Ribotta, D. P., \& Puppo, M. (2016). Traditional food products from Prosopis sp. flour. In K. Kristbergsson, \& J. Oliveira (Eds.), Part III. Traditional cereal based productsTraditional Foods (p. 209). https://doi.org/10.1007/978-1-4899-7648.

Seo, C. R., Yi, B. R., Oh, S., Kwon, S. M., Kim, S., Song, N. J., et al. (2015). Aqueous extracts of hulled barley containing coumaric acid and ferulic acid inhibit adipogenesis in vitro and obesity in vivo. Journal of Functional Foods, 12, 208-218.

Shahidi, F., \& Yeo, J. (2018). Bioactivities of phenolics by focusing on suppression of chronic diseases: A review. International Journal of Molecular Sciences, 19, 1573-1589.

Silagadze, M. A., Pruidze, E. G., Gachechiladze, S. T., Pkhakadze, G. N., \& Khvadagiani, K. B. (2017). Obtaining and a comprehensive study of highly bioavailable functional food additives based on Georgian soya varieties. Annals of Agrarian Science, 15, 356-360.

Singh, B., Singh, J., Kaur, A., \& Singh, N. (2017). Phenolic composition and antioxidant potential of grain legume seeds: A review. Food Research International, 101, 1-16.
Singleton, V. L., Orthofer, R., \& Lamuela-Raventos, R. M. (1999). Analysis of total phenols and other oxidation substrates and antioxidants by means of Folin-Ciocalteu reagent. Method in Enzymology, 299, 152-178.

Srichuwong, S., Curti, D., Austin, S., King, R., Lamothe, L., \& Gloria-Hernandez, H. (2017). Physicochemical properties and starch digestibility of whole grain sorghums, millet, quinoa and amaranth flours, as affected by starch and non-starch constituents. Food Chemistry, 233, 1-10.

Tan, Y., \& Chang, S. K. C. (2017). Digestive enzyme inhibition activity of the phenolic substances in selected fruits, vegetables and tea as compared to black legumes. Journal of Functional Foods, 38, 644-655.

Tan, Y., Chang, S. K. C., \& Zhang, Y. (2017). Comparison of a-amylase, a-glucosidase and lipase inhibitory activity of the phenolic substances in two black legumes of different genera. Food Chemistry, 214, 259-268.

Torrelio Martos, A. G., \& López, E. P. (2018). Chemical composition, percent of dietary reference intake, and acceptability of gluten-free bread made from Prosopis nigra flour, added with hydrocolloids. Food Science and Technology, 38(4), 619-624.

Valentao, P., Fernandes, E., Carvalho, F., Andrade, P. B., Seabra, R. M., \& Bastos, M. L. (2002). Antioxidative properties of Cardoon (Cynara cardunculus L.) infusion against superoxide radical, hydroxyl radical, and hypochlorous acid. Journal of Agricultural and Food Chemistry, 50(17), 4989-4993.

Wang, J., Chatzidimitriou, E., Wood, L., Hasanalieva, G., Markellou, E., , ... Iversen, P., et al. (2020). Effect of wheat species (Triticum aestivum vs T. spelta), farming system (organic vs conventional) and flour type (wholegrain vs white) on composition of wheat flour - results of a retail survey in the UK and Germany - 2. Antioxidant activity, and phenolic and mineral content. Food Chemistry X, 6, 100091.

Xiao, J., Capanoglu, E., Jassbi, A. R., \& Miron, A. (2016). Advance on the flavonoid C glycosides and health benefits. Critical Reviews in Food Science and Nutrition, 56(1), S29-S45.

Xu, B. J., \& Chang, S. K. C. (2007). A comparative study on phenolic profiles and antioxidant activities of legumes as affected by extraction solvents. Journal of Food Science, 72(2), 159-166.

Zhang, B., Deng, Z., Ramdath, D. D., Tang, Y., Chen, P. X., Liu, R., et al. (2015). Phenolic profiles of 20 Canadian lentil cultivars and their contribution to antioxidant activity and inhibitory effects on $\alpha$-glucosidase and pancreatic lipase. Food Chemistry, 172, $862-872$. 